\title{
Label-Free Rapid and Simple Detection of Exonuclease III Activity with DNA-Templated Copper Nanoclusters
}

\author{
Chunghyun Lee and Jongback Gang* \\ Department of Nanochemistry, Gachon University, Sungnam 13120, Republic of Korea
}

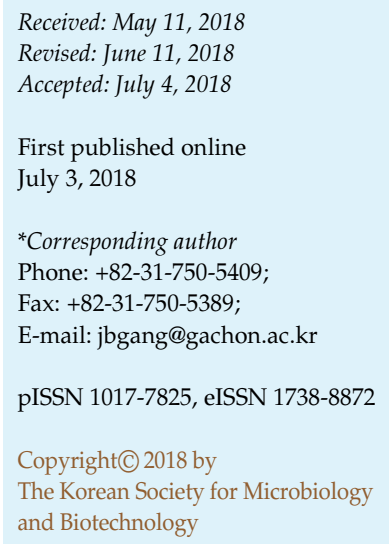

In this study, DNA-templated copper nanoclusters (DNA-CuNCs) were used to detect exonuclease III (Exo III) activity, which is important for the diagnosis and therapy of several diseases. The results of this study showed that Exo III was affected by the concentrations of magnesium ions and sodium ions, and its optimal conditions for cleavage were $5 \mathrm{mM} \mathrm{Mg}^{2+}$ and less than $25 \mathrm{mM} \mathrm{Na}^{+}$. With a blunt-end DNA, more than $98 \%$ of DNA was digested by Exo III. As expected, with two or four cytosines in the terminal position of a 4-base overhanging DNA such as 5'-GGCC-3' and 5'-CCCC-3', there was little cleavage by Exo III compared with a blunt-end DNA.

Keywords: Exonuclease III, biosensors, DNA-templated copper nanoclusters (DNA-CuNCs)

\section{Introduction}

DNA exonucleases are enzymes that digest the phosphodiester bond of DNA sequence at $3^{\prime}$-termini or $5^{\prime}$ termini. In the exonuclease family, $3^{\prime}-5^{\prime}$ exonuclease plays important roles in a variety of cellular and physiological processes, such as DNA proofreading [1] and repair [2-4]. Both the over-expression and lack of $3^{\prime}-5^{\prime}$ exonuclease activity will cause serious diseases and lead to greater susceptibility to cancers and other diseases under stress conditions [5-7]. Thus, it is important to detect $3^{\prime}-5^{\prime}$ exonuclease activity for the diagnosis and therapy of several diseases.

The detection method of $3^{\prime}-5^{\prime}$ exonuclease activity involves radioisotope-utilized gel electrophoresis [8]. However, these techniques are highly labor intensive and associated with safety problems [9]. Fluorescence-based methods have been developed for the detection of DNA sequences and enzyme activities, such as polymerase, ligase, and endonucleases [10-13]. The reported fluorescence methods require organic dyes to label DNA probes. However, these organic dyes cause serious photo bleaching and lead to irreproducible results [14].

Recently, noble metal nanoclusters have been developed for use in biological labeling, biosensors, bioimaging, and diagnostic applications. Specifically, oligonucleotide-templated nanoclusters have attracted attention for utilization in biological analysis due to their facile synthesis, photo stability and photophysical properties [14]. For example, DNA-templated $\mathrm{Ag}^{+}$nanoclusters (DNA-AgNCs) have been widely used to detect DNA sequence, small biomolecules, enzymes, and proteins [15-17]. However, there are several problems associated with the use of DNA-AgNCs for applications: 1) $\mathrm{Ag}^{+}$ions form an insoluble product with many anions, such as $\mathrm{Cl}^{-}$or $\mathrm{SO}_{4}{ }^{2-}$, that will terminate the formation of DNA-AgNCs, 2) $\mathrm{Mg}^{2+}$ ions in the reaction buffer also affect the formation of DNA-AgNCs [18], 3) the synthesis of DNA-AgNCs takes one to several hours involving the reduction of $\mathrm{Ag}^{+}$ions with $\mathrm{NaBH}_{4}[16,19,20]$.

In contrast, the newly emerging DNA-templated copper nanoclusters (DNA-CuNCs) show excellent potential for use in rapid and simple mix-and-measure assays for the detection of mismatched DNA and enzymes activities in a duplex DNA [14, 21, 22]. DNA-CuNCs can be easily prepared by the reduction of $\mathrm{Cu}^{2+}$ ions with ascorbic acid in the presence of a duplex DNA within several minutes. Moreover, $\mathrm{Cu}^{2+}$ ions are soluble in detection solutions and thus do not precipitate, unlike Ag+ ions. In this study, 
Table 1. The oligonucleotides used in this study.

\begin{tabular}{ll}
\hline Name & \multicolumn{1}{c}{ Sequence $\left(5^{\prime} \rightarrow 3^{\prime}\right)$} \\
\hline tDNA & CAA TAT TTA TAT ATT ATA TTT AGA GT \\
cDNA-1 & TAT AAT ATA TAA ATA TTG \\
cDNA-2 & TAT AAT ATA TAA ATA TTG GGC C \\
cDNA-3 & TAT AAT ATA TAA ATA TTG CCC C \\
\hline
\end{tabular}

exonuclease III (Exo III) activity was measured with different DNA at different concentrations of Exo III by using DNA-CuNCs.

\section{Materials and Methods}

The oligonucleotides used in this work were purchased from Bioneer (Korea) and were purified by PAGE. Copper nitrate $\left(\mathrm{Cu}\left(\mathrm{NO}_{3}\right)_{2}\right)$, sodium ascorbate, and nitric acid $\left(\mathrm{HNO}_{3}\right)$ were purchased from Sigma Aldrich (USA). Tris (hydroxymethyl) aminomethane (TRIS) was purchased from USB (USA). Sodium nitrate $\left(\mathrm{NaNO}_{3}\right)$ and magnesium nitrate $\left(\mathrm{Mg}\left(\mathrm{NO}_{3}\right)_{2}\right)$ were purchased from Junsei Chemical (Japan). Exo III was purchased from Takara Biotechnology (Japan). All solutions were prepared with deionized water from Millipore water systems (Millipore Synergy UV, Mosheim, France).

\section{Exo III Assay}

Duplex DNA was prepared with upper and down strands DNA (Table 1) in $10 \mathrm{mM}$ Tris ( $\mathrm{pH} 8.0$ ) and $50 \mathrm{mM} \mathrm{NaNO}$. After incubation at $85^{\circ} \mathrm{C}$ for $10 \mathrm{~min}$, solutions were cooled down slowly overnight. The Exo III assay was conducted by adding different amounts of Exo III to $4 \mu \mathrm{M}$ of duplex DNA in reaction buffer (10 mM Tris- $\mathrm{HNO}_{3}, 5 \mathrm{mM} \mathrm{Mg}\left(\mathrm{NO}_{3}\right)_{2}, 50 \mathrm{mM} \mathrm{NaNO}$ at $\mathrm{pH}$ 8.0). Other reactions were also conducted with 4 nucleotides overhanging DNAs containing 5'-GGCC-3' (cDNA-2) or 5'-CCCC-3' (cDNA-3).

\section{Effect of Sodium and Magnesium Ions on ExoIII Activity}

To measure the effect of salt ions on Exo III activity, sodium ions were used at concentrations from 0 to $200 \mathrm{mM}$ in the reactions.
In addition, magnesium ions were used at concentrations from 0 to $10 \mathrm{mM}$ in the reactions. Exo III activity was monitored by the measurement of fluorescence intensity in the presence of salt ions.

\section{Preparation of DNA-CuNCs}

After the Exo III cleavage reaction, copper nitrate solution $(100 \mu \mathrm{M})$ and the freshly prepared sodium ascorbate solution $(100 \mathrm{mM})$ were added to the reaction mixture. Reaction mixtures were vortexed and incubated in the dark for $10 \mathrm{~min}$ at room temperature $\left(\sim 20^{\circ} \mathrm{C}\right)$. The fluorescence emission of the reaction was measured at the excitation wavelength of $345 \mathrm{~nm}$ and emission wavelength of $610 \mathrm{~nm}$.

\section{Instrumentation}

Fluorescence emission was measured with a Spectra Max M2 Microplate Reader (Molecular Devices, USA). Fluorescence emission spectra were scanned from 520 to $700 \mathrm{~nm}$ at an excitation wavelength of $345 \mathrm{~nm}$. In addition, fluorescence excitation spectra were also collected from 300 to $400 \mathrm{~nm}$ at an emission wave length of $610 \mathrm{~nm}$.

\section{Results and Discussion}

\section{Principle of Detection Strategy for Exo III Activity}

The assay strategy for Exo III is depicted in Scheme 1. This study used duplex DNA molecules with three different types of DNA ends: tDNA:cDNA-1 (bluntendDNA), tDNA:cDNA-2 (5'-GGCC-3' overhanging DNA), and tDNA:cDNA-3 (5'-CCCC-3' overhanging DNA) as substrates for Exo III. A duplex DNA contained a 5'TTTAGAGT-3' overhanging end for protection from Exo III cleavage and the blunt end as a substrate for Exo III (shown in Scheme 1). In addition, aduplex DNA contained an adenine-thymidine (AT)-rich sequence for copper nanocluster formation through interactions among copper ion and A-T paired bases of duplex DNA. On the addition of $\mathrm{Cu}^{2+}$ and ascorbic acid, DNA-templated $\mathrm{Cu}$ nanoclusters formed through the reduction of $\mathrm{Cu}(\mathrm{II})$ to $\mathrm{Cu}(\mathrm{I})$ followed

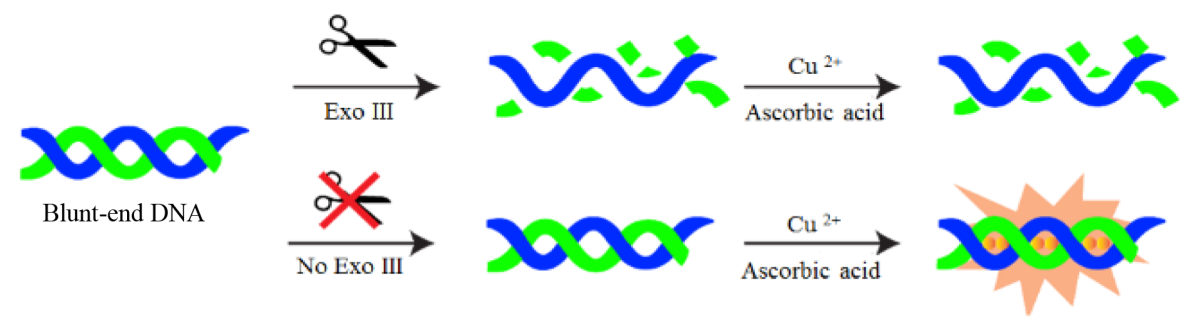

Scheme 1. Schematic representation of the Exo III assay.

Blunt-end DNA has blunt-end DNA at the 5' end, but the 3' end of DNA contains 8 bases overhanging the end. DNA was treated with Exo III, and then DNA-CuNCs were synthesized for the fluorescence measurement (top). In the control, DNA-CuNCs were synthesized without Exo III treatment (bottom). 


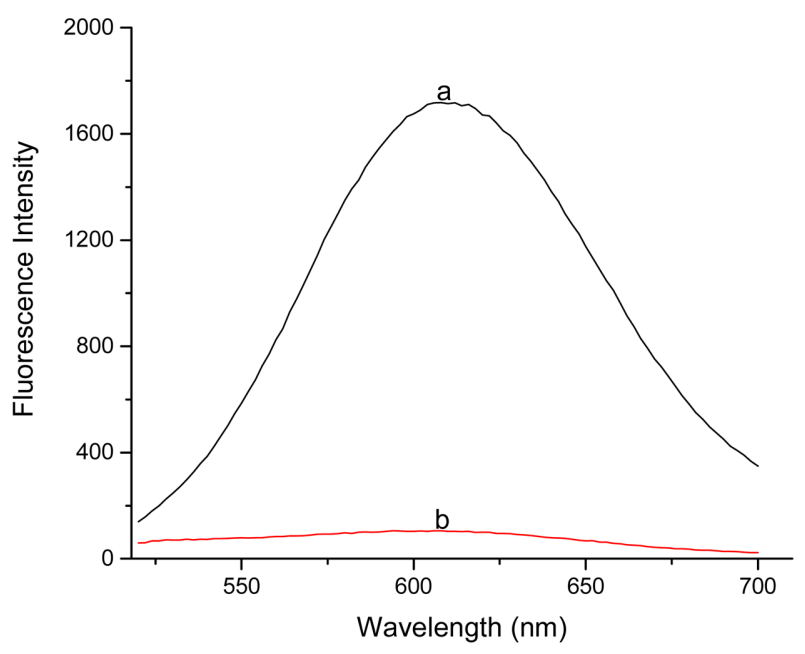

Fig. 1. Fluorescence intensities of the KF-assay without Exo III (a) and with $20 \mathrm{U} / \mathrm{ml}$ of Exo III (b).

Fluorescence emission was scanned from 520 to $700 \mathrm{~nm}$ at excitation wavelength of $345 \mathrm{~nm}$.

by the disproportionation of $\mathrm{Cu}(\mathrm{I})$ into $\mathrm{Cu}(\mathrm{II})$ and $\mathrm{Cu}(0)$ [24-26]. The formation of DNA-CuNCs resulted in strong fluorescence emission. In contrast, Exo III treatment of duplex DNA decreased the fluorescence intensity significantly.

\section{Optimization of Assay Conditions}

The fluorescence spectra shown in Fig. 1 were recorded at wavelengths from 520 to $700 \mathrm{~nm}$ either in the presence (b) or absence (a) of Exo III. The results indicated that Exo III treatment of blunt-end DNA led to a significant decrease in fluorescence intensity at $20 \mathrm{U} / \mathrm{ml}$ of Exo III. The fluorescence intensity of Exo III-treated blunt-end DNA was $6.0 \%$ of that in the absence of Exo III.

As shown in Fig. 2A, Exo III assays were conducted with different concentrations of blunt-end DNA. The fluorescence intensity was high enough to detect ExoIII activity with $1.0 \mu \mathrm{M}$ DNA under the different conditions compared to that with $0 \mu \mathrm{M}$ DNA as a background (Fo). The signal to background ratio $(\mathrm{S} / \mathrm{B}), \Delta \mathrm{F} / \mathrm{Fo}(\Delta \mathrm{F}=\mathrm{F}-\mathrm{Fo}, \mathrm{F}$ represents fluorescence intensities at any DNA concentration) was 62.7. In addition, fluorescence intensities were linear correlated with DNA concentrations $\left(\mathrm{R}^{2}=0.995\right.$ in Fig. 2B). These results indicated that DNA-CuNCs were effective for detecting Exo III activity with high sensitivity.

\section{Effect of Metal Ions on Exo III Activity}

To determine the optimal concentration of $\mathrm{Mg}^{2+}$ for Exo III activity, the hydrolytic cleavage of Exo III was performed with different concentrations of magnesium ions (Fig. 3A).
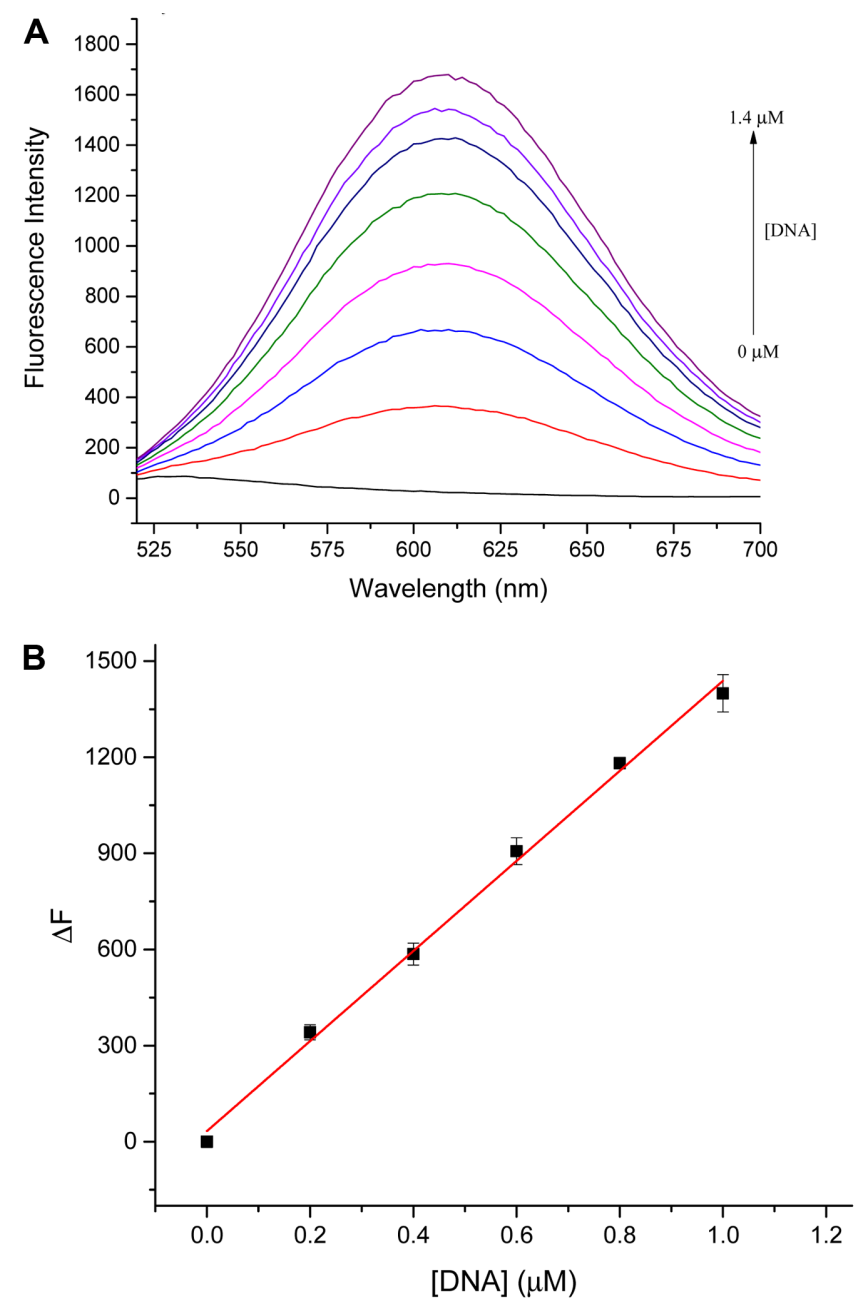

Fig. 2. (A) Fluorescence emission spectra at different concentrations of blunt-end DNA from 0 to $1.4 \mu \mathrm{M}$. (B) Linear correlation of $\Delta \mathrm{F}$ with DNA concentrations used in this study. $\Delta \mathrm{F}=\mathrm{F}-\mathrm{Fo}$. $\mathrm{F}$ represented fluorescence intensities at any DNA concentration and Fo contained no DNA.

The cleavage reaction of Exo III was activated as the concentration of $\mathrm{Mg}^{2+}$ ions increased, and maximal activity was reached at $5 \mathrm{mM} \mathrm{Mg}^{2+}$. According to the crystal structure of Exo III [26], the $\beta$ strands between Exo III and RNase $\mathrm{H}$ are superimposed and positioned at active sites that share the putative catalytic residues (RNase H Asp 70 and His 124 versus Exo III Asp 229 and His 259). In addition, Exo III has a similar fold around the metal binding site as RNase H and DNase I [26, 27]. Thus, Exo III activation and inhibition by metal ions can be understood based on the reaction mechanism of RNase H. By results from the initial velocity of RNase $\mathrm{H}$ at different concentrations of $\mathrm{Mg}^{2+}$, it maximally increased with $5 \mathrm{mM}$ 

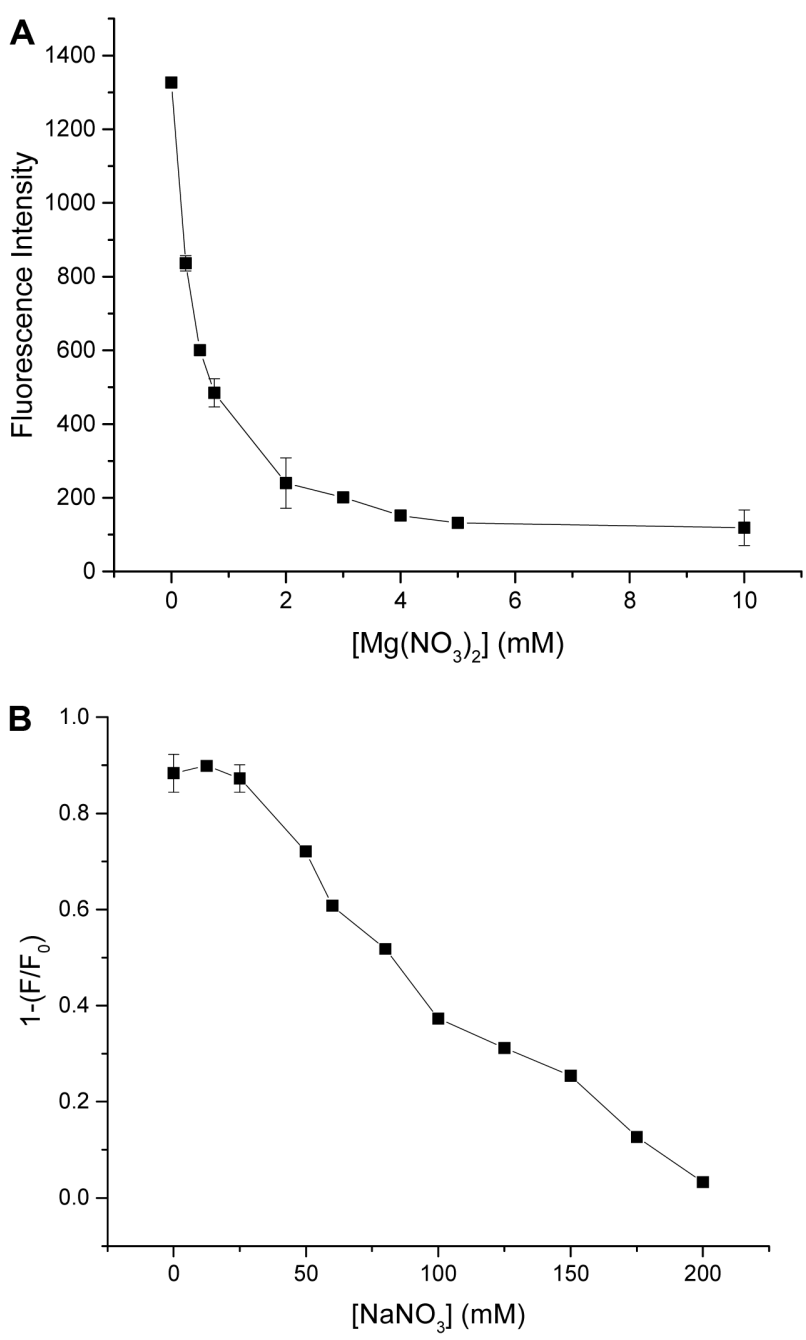

Fig. 3. (A) Dependence of Exo III activity on $\mathrm{Mg}^{2+}$ concentrations from 0 to $10 \mathrm{mM}$. (B) The effect of $\mathrm{Na}^{+}$ion on Exo III activity was measured with sodium concentrations from 0 to $200 \mathrm{mM}$ by using 1-(F/Fo) (digestion fraction).

of $\mathrm{Mg}^{2+}$ ions but an inhibitory effect was observed at higher $\mathrm{Mg}^{2+}$ concentrations, presumably due to the binding of metal ions to the negatively-charged polynucleotide [28].

In addition, Exo III activity was measured at various concentrations of $\mathrm{Na}^{+}$ions in the presence of $5 \mathrm{mM}$ of $\mathrm{Mg}^{2+}$ (Fig. 3B). 1-F/Fo (digestion fraction) was not affected by the addition of $\mathrm{Na}^{+}$ions up to $25 \mathrm{mM} \mathrm{Na}^{+}$. However, Exo III activity decreased gradually at sodium ion concentrations from 25 to $200 \mathrm{mM}$. It has been reported that increases in the $\mathrm{NaCl}$ concentration decreases the Exo III activity gradually over the whole range of enzyme concentrations from $20 \mathrm{U}$ at $120 \mathrm{U} / \mu \mathrm{g}$ DNA $[9,29]$. In addition, RNase $\mathrm{H}$ showed a lower binding affinity for magnesium ions at

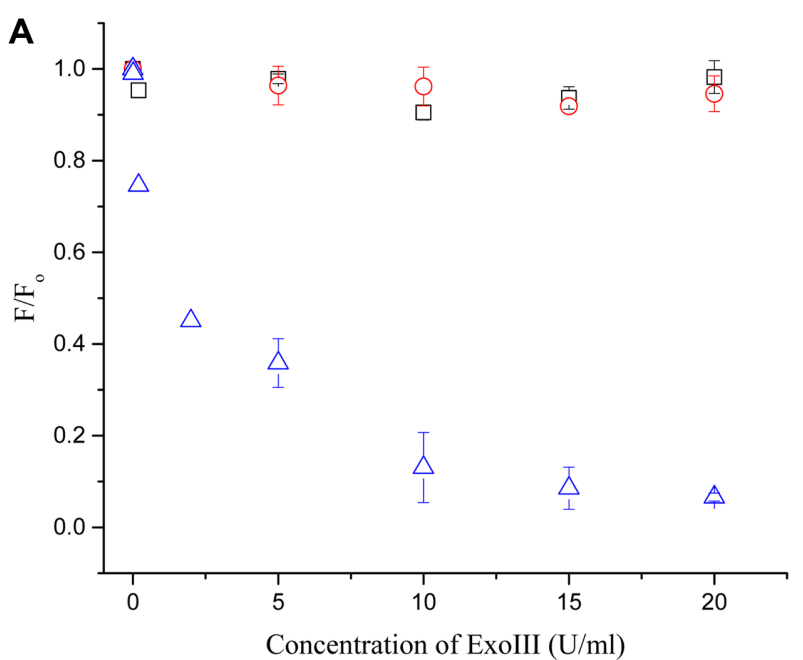

B

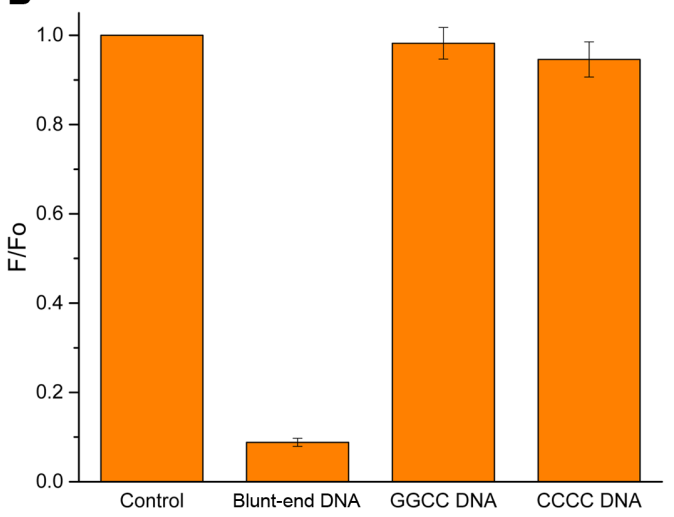

Fig. 4. (A) F/Fo values were plotted against the different concentrations of Exo III from 0 to $20 \mathrm{U} / \mathrm{ml}$. The data from the Exo III assay with blunt-end DNA $(\triangle)$, 5'-GGCC-3' overhanging DNA $(\square)$, or 5'-CCCC-3' overhanging DNA (O). (B) F/Fo from Exo III assay $(20 \mathrm{U} / \mathrm{ml})$ with three different types of DNA.

higher $\mathrm{Na}^{+}$concentration in reaction with $10 \mathrm{mM} \mathrm{Mg}^{2+}$ [28]

\section{Performance of Exo III with Different types of DNA}

Fig. 4A shows a plot of F/Fo against Exo III concentration in the presence of blunt-end DNA, 5'-GGCC-3' and 5'CCCC -3 ' overhanging DNA. F and Fo are the fluorescence intensities at any concentration of Exo III and at with no Exo III, respectively. At low concentration of Exo III, fluorescence intensities decreased rapidly in blunt-end DNA. In 5'-GGCC-3' and 5'-CCCC-3' overhanging DNA, however, little DNA digestion occurred with $5.0 \mathrm{U} / \mathrm{ml}$ of Exo III according to digestion fraction (1-F/Fo), which was less than 0.06. It was concluded that blunt-end DNA was a better substrate for hydrolytic cleavage by Exo III than 5'- 
GGCC-3' and 5'-CCCC-3' overhanging DNA. By using molecular beacon DNA with a polythymine loop as a template for the formation of fluorescence copper nanoparticles, Exo III activity was sensitively detected by measuring fluorescence intensity for digestion of molecular beacon probe [30].

In Fig. 4B, DNA cleavage by Exo III is indicated by F/Fo in the presence of blunt-end DNA, and 5'-GGCC-3' and 5'CCCC-3' overhanging DNA at $20 \mathrm{U} / \mathrm{ml}$ Exo III. The results indicated that more than $98 \%$ of duplex DNA was digested in blunt-end DNA. For 5'-GGCC-3' and 5'-CCCC-3' overhanging DNA, the digestion fraction did not differ between them at high concentration of Exo III. It has been reported that a single cytosine in the terminal position of 4-base overhanging DNA requires a higher enzyme concentration and longer incubation to achieve degradation similar to that with 4-base overhanging DNA which contains two adjacent cytosine nucleotides in the terminal position $[9,31]$.

In conclusion, this study showed that Exo III activity was dependent on the concentrations of magnesium ions and sodium ions and the optimal conditions were $5 \mathrm{mM} \mathrm{Mg}^{2+}$ and less than $25 \mathrm{mM} \mathrm{Na}^{+}$. In addition, Exo III digested more than $98 \%$ of blunt-end DNA. However, the treatment of 5'-GGCC-3' and 5'-CCCC-3' overhanging DNA with Exo III resulted in little cleavage compared to that with bluntend DNA.

\section{Conflict of Interest}

The authors have no financial conflicts of interest to declare.

\section{References}

1. Gammon DB, Evans DH. 2009. The $3^{\prime}-$ to $-5^{\prime}$ exonuclease activity of vaccinia virus DNA polymerase is essential and plays a role in promoting virus genetic recombination. $J$. Virol. 83: 4236-4250.

2. Song L, Chaudhuri M, Knopf CW, Parris DS. 2004. Contribution of the $3^{\prime}$ - to $5^{\prime}$-exonuclease activity of herpes simplex virus type 1 DNA polymerase to the fidelity of DNA synthesis. J. Biol. Chem. 279: 18535-18543.

3. Shevelev LV, Huescher U. 2002. The 3' 5' exonucleases. Nat. Rev. Mol. Cell Biol. 3: 364-376.

4. Wu X, Chen J, Zhao JX. 2014. Ultrasensitive detection of 3'$5^{\prime}$ exonuclease enzymatic activity using molecular beacons, Analyst 139: 1081-1087.

5. Paul TT, Gellert M. 1998. The 3' to 5' exonuclease activity of Mre 11 facilitates repair of DNA double-strand breaks. Mol.
Cell 1: 969-979.

6. Kavanagh D, Spitzer D, Kothari PH, Shaikh A, Liszewski MK, Richards A, Atkinson JP. 2008. New roles for the major human $3^{\prime}-5^{\prime}$ exonuclease TREX1 in human disease. Cell Cycle 7: 1718-1725.

7. Leung CH, Chan DS, Man BY, Wang CJ, Lam W, Cheng YC, Fong WF, et al. 2011. Simple and convenient G-quadruplexbased turn-on fluorescence assay for $3^{\prime} \rightarrow 5^{\prime}$ exonuclease activity. Anal. Chem. 83: 463-466.

8. Brucet M, Querol-Audi J, Bertlik K, Lioberas J, Fita I, Celada A. 2008. Structural and biochemical studies of TREX1 inhibition by metals. Identification of a new active histidine conserved in DEDDh exonucleases. Protein Sci. 17: 2059-2069.

9. Hoheisel JD. 1993. On the activities of Escherichia coli exonuclease III. Anal. Biochem. 209: 238-246.

10. Chen Y, Yang CJ, Wu Y, Conlon P, Kim Y, Lin H, Tan W. 2008. Light-switching excimer beacon assays for ribonuclease H kinetic study. Chem. Biochem. 9: 355-359.

11. Tan W, Wang K, Drake TJ. 2004. Molecular beacons. Curr. Opin. Chem. Biol. 8: 547-553.

12. Tang Z, Liu P, Ma C, Yang X, Wang K, Tan W, et al. 2011. Molecular beacon based bioassay for highly sensitive and selective detection of nicotinamide adenine dinucleotide and the activity of alanine aminotransferase. Anal. Chem. 83: 2505-2510.

13. Dai N, Kool ET. 2011. Fluorescent DNA-based enzyme sensors. Chem. Soc. Rev. 40: 5756-5770.

14. Wang XP, Yin BC, Ye BC. 2013. A novel fluorescence probe of dsDNA-templated copper nanoclusters for quantitative detection of microRNAs. RSC Adv. 3: 8633-8636.

15. Richards CI, Choi S, Hsiang JC, Antoku Y, Vosch T, Bongiorno A, et al. 2008. Oligonucleotide-stabilized Ag nanoclusters fluorophores. J. Am. Chem. Soc. 130: 5038-5039.

16. Yeh H, Sharma J, Han JJ, Martinez JS, Werner JH, 2010. A DNA-silver nanoclusters probe that fluoresces upon hybridization. Nano Lett. 10: 3106-3110.

17. Gwinn EG, Neill P, Guerrero A, Bouwmeester D, Fygenson DDK. 2008. Sequence-dependent fluorescence of DNAhosted silver nanoclusters. Adv. Mater. 20: 279-283.

18. Ma K, Cui Q, Shao Y, Wu F, Xu S, Liu G, 2012. Emission modulation of DNA-templated fluorescent silver nanoclusters by divalent magnesium ion. J. Nanosci. Nanotechnol. 12: 861-869.

19. Xu H, Suslick KS. 2010. Water-soluble fluorescent silver nanoclusters. Adv. Mater. 22: 1078-1082.

20. Han B, Wang E. 2011. Oligonucleotide-stabilized fluorescent silver nanoclusters for sensitive detection of biothiols in biological fluids. Biosens. Bioelectron. 26: 2585-2589.

21. Jia X, Li J, Han L, Ren J, Yang X, Wang E. 2012. DNAhosted copper nanoclusters for fluorescent identification of single nucleotide polymorphisms. ACS Nano 6: 3311-3317.

22. Zhou F, Cui X, Shang A, Lian J, Yang L, Jin Y, et al. 2017. Fluorometric determination of the activity and inhibition of terminal deoxynucleotidyl transferase via in-situ formation 
of copper nanoclusters using enzymatically-generated DNA as template. Microchim. Acta 184: 773-779.

23. Zhao H, Dong J, Zhou F, Li B, 2017. One facile fluorescence strategy for sensitive detection of endonuclease activity using DNA-templated copper nanoclusters as signal indicators. Sens. Actuators B Chem. 238: 828-833.

24. Song Q, Shi Y, He D, Xu S, Ouyang J, 2015. Sequencedependent dsDNA-templated formation of fluorescent copper nanoparticles. Chem. Eur. J. 21: 2417-2422.

25. Qing T, Qing Z, Mao Z, He X, Xu F, Wen L, et al. 2014. dsDNA-templated fluorescent copper nanoparticles: poly(ATTA)-dependent formation. RSC Adv. 4: 61092-61095.

26. Mol CD, Kuo CF, Thayer MM, Cunningham RP, Tainer JA. 1995. Structure and function of the multifunctional DNArepair enzyme exonuclease III. Nature 374: 381-386.
27. Katayanagi K, Miyagawa M, Matsushima M, Ishikawa M, Kanaya S, Ikehara M, et al. 1990. Three-dimensional structure of ribonuclease $\mathrm{H}$ from E. coli. Nature 347: 306-309.

28. Black CB, Cowan JA, 1994. Magnesium activation of ribonuclease $\mathrm{H}$. evidence for one catalytic metal ion. Inorg. Chem. 33: 5805-5808.

29. Tomb JF, Barcak GJ. 1989. Regulating the $3^{\prime}-5^{\prime}$ activity of exonuclease III by varying the sodium chloride concentration. BioTechniques 7: 932-933.

30. Ge J, Dong Z-Z, Bai D-M, Zhang L, Hu Y-L, Ji D-Y, et al, 2017. A novel label-free fluorescent molecular beacon for the detection of 30-50 exonuclease enzymaticactivity using DNAtemplated copper nanoclusters. New J. Chem. 41: 9718-9723.

31. Linxweiler W, Horz W, 1982. Sequence specificity of exonuclease III from E. coli. Nucleic Acids Res. 10: 4845-4859. 